\title{
ELEMENTAL BIOAVAILIBILITY IN NUTRIENT SOLUTIONS IN RELATION TO DISSOCIATION REACTIONS
}

\author{
De Rijck G. and Schrevens E. \\ Faculty of Agricultural and Applied Biological Sciences \\ Department of Applied Plant Sciences K.U.Leuven \\ Willem de Croylaan 42, B-3001 Heverlee (Belgium)
}

\section{$\underline{\text { ABSTRACT }}$}

In general in hydroponic plant nutritional research, as well as in commercial hydroponic plant cropping, the actual nutritional composition is supposed to be exactly the same as the desired one. Furthermore, it is supposed that the nutrients are present in the nutrient solution as free ions. This way of thinking does not take into account the dissociation, complexation and precipitation reactions, occurring in nutrient solutions. These chemical reactions seriously impact elemental speciation and bioavailability. As a result plants will experience a completely different nutritional composition.

An accurate description of the chemical reactions occurring in nutrient solutions gives an accurate insight into mineral composition offered to the plants. This additional information is a valuable tool in interpreting specific effects of the mineral composition of the nutrient solution on dependent variables.

A good knowledge of the chemical reactions occurring in nutrient solutions is the first prerequisite in hydroponic plant nutritional research. In this study the 
dissociation reactions occurring in nutrient solutions are investigated. The dissociation reactions of phosphate and carbonate influence both the mineral composition of the nutrient solutions and their bioavailability.

\section{INTRODUCTION}

Nutrient solutions can be considered as aqueous solutions of inorganic ions. In these aqueous solutions the elements are not present as free ions. A dynamic equilibrium between dissociation, precipitation and complexation reactions results in a specific elemental speciation. The term speciation indicates the distribution of elements among their various chemical and physical forms like: free ions, soluble complexes, chelates, ionpairs, solid and gaseous phases and different oxidation states, all of which influences their reactivity, mobility and bioavailability. A good knowledge of the chemical reactions occurring in nutrient solutions is the first prerequisite in hydroponic plant nutritional research.

Considering only the six essential macronutrients, nutrient solutions can be considered as an aqueous solutions containing $\mathrm{K}^{+}, \mathrm{Ca}^{2+}, \mathrm{Mg}^{2+}, \mathrm{NO}_{3}{ }^{-}, \mathrm{H}_{2} \mathrm{PO}_{4}{ }^{-}$and $\mathrm{SO}_{4}{ }^{2-}$ ions. Lots of standard nutrient solutions contain ammonia in a millimolar range. In practice sometimes tapwater is used, containing bicarbonate in a millimolar range. Therefore also the dissociation reactions of $\mathrm{NH}_{4}{ }^{+}$and $\mathrm{HCO}_{3}{ }^{-}$ are described.

According to the $\mathrm{pH}$ these ions can be present in different dissociation forms. The influence of the $\mathrm{pH}$ on the dissociation of these ions is investigated and represented in figures. 


\section{MATERIAL AND METHODS}

In the calculations the impact of the atmospheric pressure and composition and the impact of the temperature are not taken into accounted. The used equilibrium constants are only strictly correct at $25^{\circ} \mathrm{C}$, at a constant ionic strength and at an atmospheric pressure of 101325 pascal.

The fraction of the different dissociation forms present in function of the $\mathrm{pH}$, are calculated based on their ionisation constants and represented in figures for a $\mathrm{pH}$ range from 1 to 14 . These calculations are correct if only the respective ions are present. The magnitude of the acid (base) ionisation constant gives an indication of the extent to which an acid (base) ionises. Strong acids like $\mathrm{HNO}_{3}$ and $\mathrm{H}_{2} \mathrm{SO}_{4}$ and strong bases like $\mathrm{KOH}, \mathrm{Ca}(\mathrm{OH})_{2}$ and $\mathrm{Mg}(\mathrm{OH})_{2}$ are completely dissociated in the considered $\mathrm{pH}$ range.

The positive ion " $\mathrm{H}_{3} \mathrm{O}^{+}$", formed by a covalent bounding of the proton to $\mathrm{H}_{2} \mathrm{O}$, involving one of the unshared electron pairs of the oxygen is called the hydrogen ion. Higher hydrates such as $\mathrm{H}_{5} \mathrm{O}_{2}{ }^{+}$and $\mathrm{H}_{7} \mathrm{O}_{3}{ }^{+}$are also present, but their stabilities are significantly less than that of $\mathrm{H}_{3} \mathrm{O}^{+}$. No unhydrated hydrogen ions appear to exist in aqueous solutions, (Skoog et al., 1976). All protons in water are undergoing rapid migration from one oxygen to another. The average lifetime of an individual $\mathrm{H}_{3} \mathrm{O}^{+}$ion is $10^{-13}$ seconds. The rate of reaction of $\mathrm{H}_{3} \mathrm{O}^{+}$ with a base such as $\mathrm{OH}^{-}$in water is very fast but diffusion controlled (Cotton et al., 1980).

\section{$\underline{\text { RESULTS AND DISCUSSION }}$}

\section{$\underline{1 . \text { Nitric acid }}$}

Nitric acid is a rather strong monoprotic acid, completely dissociated between $\mathrm{pH} 1$ to 14 (Figure 1). Taking only dissociation reactions into account, the amount of nitrate in a nutrient solution is completely present as $\mathrm{NO}_{3}{ }^{-}$. 


$$
\mathrm{HNO}_{3}+\mathrm{H}_{2} \mathrm{O} \rightarrow \mathrm{NO}_{3}^{-}+\mathrm{H}_{3} \mathrm{O}^{+} \quad \mathrm{K}_{\mathrm{a}}=10^{1.4}
$$

\section{Phosphoric acid}

The polyprotic acid $\mathrm{H}_{3} \mathrm{PO}_{4}$ contains three ionisable protons, dissociating in three distinct steps. Each successive dissociation has a lower disscociation and is energetically less favourable $\left(\mathrm{K}_{\mathrm{a} 3}<\mathrm{K}_{\mathrm{a} 2}<\mathrm{K}_{\mathrm{a} 1}\right)$ :

$$
\begin{array}{ll}
\text { 1. } \mathrm{H}_{3} \mathrm{PO}_{4}+\mathrm{H}_{2} \mathrm{O} \leftrightarrow \mathrm{H}_{3} \mathrm{O}^{+}+\mathrm{H}_{2} \mathrm{PO}_{4}^{-} & \mathrm{K}_{\mathrm{a} 1}=10^{-2.1} \\
\text { 2. } \mathrm{H}_{2} \mathrm{PO}_{4}^{-}+\mathrm{H}_{2} \mathrm{O} \leftrightarrow \mathrm{H}_{3} \mathrm{O}^{+}+\mathrm{HPO}_{4}{ }^{2-} & \mathrm{K}_{\mathrm{a} 2}=10^{-7.2} \\
\text { 3. } \mathrm{HPO}_{4}{ }^{2-}+\mathrm{H}_{2} \mathrm{O} \leftrightarrow \mathrm{H}_{3} \mathrm{O}^{+}+\mathrm{PO}_{4}{ }^{3-} & \mathrm{K}_{\mathrm{a} 3}=10^{-12.3}
\end{array}
$$

Dissolving $\mathrm{H}_{3} \mathrm{PO}_{4}$ in water results in the formation of a considerable amount of $\mathrm{H}_{2} \mathrm{PO}_{4}{ }^{-}$. The second acid ionisation constant $\left(\mathrm{K}_{\mathrm{a} 2}\right)$ is much smaller than the first $\left(\mathrm{K}_{\mathrm{a} 1}\right)$. The amount of $\mathrm{H}_{2} \mathrm{PO}_{4}{ }^{-}$that further dissociates to $\mathrm{HPO}_{4}{ }^{2-}$ is very small. In function of the $\mathrm{pH}$ different dissociation forms of phosphoric acid will be formed (Figure 2). The fraction $\mathrm{H}_{3} \mathrm{PO}_{4}\left(\alpha_{0}\right), \mathrm{H}_{2} \mathrm{PO}_{4}{ }^{-}\left(\alpha_{1}\right), \mathrm{HPO}_{4}{ }^{2-}\left(\alpha_{2}\right)$, and $\mathrm{PO}_{4}{ }^{3-}\left(\alpha_{3}\right)$, present in function of the $\mathrm{pH}$ can be calculated as follows:

1. The fraction $\mathrm{H}_{3} \mathrm{PO}_{4}: \alpha_{0}=1 / \mathrm{A}$

2. The fraction $\mathrm{H}_{2} \mathrm{PO}_{4}^{-}: \alpha_{1}=\left(\mathrm{K}_{\mathrm{a} 1}\left[\mathrm{H}_{3} \mathrm{O}^{+}\right]^{-1}\right) / \mathrm{A}$

3. The fraction $\mathrm{HPO}_{4}{ }^{2-}: \alpha_{2}=\left(\mathrm{K}_{\mathrm{a} 1} \mathrm{~K}_{\mathrm{a} 2}\left[\mathrm{H}_{3} \mathrm{O}^{+}\right]^{-2}\right) / \mathrm{A}$

4. The fraction $\mathrm{PO}_{4}{ }^{3-}: \alpha_{3}=\left(\mathrm{K}_{\mathrm{a} 1} \mathrm{~K}_{\mathrm{a} 2} \mathrm{~K}_{\mathrm{a} 3}\left[\mathrm{H}_{3} \mathrm{O}^{+}\right]^{-3}\right) / \mathrm{A}$

With $\mathrm{A}=1+\left(\mathrm{K}_{\mathrm{a} 1}\left[\mathrm{H}_{3} \mathrm{O}^{+}\right]^{-1}\right)+\left(\mathrm{K}_{\mathrm{a} 1} \mathrm{~K}_{\mathrm{a} 2}\left[\mathrm{H}_{3} \mathrm{O}^{+}\right]^{-2}\right)+\left(\mathrm{K}_{\mathrm{a} 1} \mathrm{~K}_{\mathrm{a} 2} \mathrm{~K}_{\mathrm{a} 3}\right.$ $\left.\left[\mathrm{H}_{3} \mathrm{O}^{+}\right]^{-3}\right)$

The denominator is the same for each fraction. The fractional amount of each species at any fixed $\mathrm{pH}$ is independent of the total concentration of phosphate. The $\mathrm{pH}$ of most nutrient solutions varies between 4 and 7. At a pH of 4.6 the phosphate in nutrient solutions is completely present in the dissociation form $\mathrm{H}_{2} \mathrm{PO}_{4}{ }^{-}$. Increasing $\mathrm{pH}$ to 7.2, equal proportions of $\mathrm{H}_{2} \mathrm{PO}_{4}{ }^{-}$and $\mathrm{HPO}_{4}{ }^{2-}$ are present. The bioavailability of $\mathrm{H}_{2} \mathrm{PO}_{4}{ }^{-}$is different than that of $\mathrm{HPO}_{4}{ }^{2-}$ (Hai et al., 
1966). In this way the $\mathrm{pH}$ of the nutrient solution influences both the composition of the nutrient solution and the bioavailability of phosphate.

\section{Sulphuric acid}

The biprotic acid $\mathrm{H}_{2} \mathrm{SO}_{4}$ dissociates in two distinct steps. It is a strong acid in its first dissociation and a somewhat weaker acid in its second dissociation step.

$$
\begin{array}{ll}
\text { 1. } \mathrm{H}_{2} \mathrm{SO}_{4}+\mathrm{H}_{2} \mathrm{O} \rightarrow \mathrm{H}_{3} \mathrm{O}^{+}+\mathrm{HSO}_{4}^{-} & \mathrm{K}_{\mathrm{a} 1}=10^{10.3} \\
\text { 2. } \mathrm{HSO}_{4}{ }^{-}+\mathrm{H}_{2} \mathrm{O} \leftrightarrow \mathrm{H}_{3} \mathrm{O}^{+}+\mathrm{SO}_{4}{ }^{2-} & \mathrm{K}_{\mathrm{a} 2}=10^{-1.9}
\end{array}
$$

In an aqueous solution of sulphuric acid there is no $\mathrm{H}_{2} \mathrm{SO}_{4}$ present but different proportions of $\mathrm{HSO}_{4}{ }^{-}$and $\mathrm{SO}_{4}{ }^{2-}$, according to the $\mathrm{pH}$ (Figure 3). The fraction $\mathrm{H}_{2} \mathrm{SO}_{4}\left(\alpha_{0}\right), \mathrm{HSO}_{4}{ }^{-}\left(\alpha_{1}\right)$ and $\mathrm{SO}_{4}{ }^{2-}\left(\alpha_{2}\right)$, present in function of the $\mathrm{pH}$ can be calculated as follows:

1. The fraction $\mathrm{H}_{2} \mathrm{SO}_{4}: \alpha_{0}=1 / \mathrm{A}$

2. The fraction $\mathrm{HSO}_{4}^{-}: \alpha_{1}=\left(\mathrm{K}_{\mathrm{a} 1}\left[\mathrm{H}_{3} \mathrm{O}^{+}\right]^{-1}\right) / \mathrm{A}$

3. The fraction $\mathrm{SO}_{4}{ }^{2-}: \alpha_{2}=\left(\mathrm{K}_{\mathrm{a} 1} \mathrm{~K}_{\mathrm{a} 2}\left[\mathrm{H}_{3} \mathrm{O}^{+}\right]^{-2}\right) / \mathrm{A}$

With $\mathrm{A}=1+\left(\mathrm{K}_{\mathrm{a} 1}\left[\mathrm{H}_{3} \mathrm{O}^{+}\right]^{-1}\right)+\left(\mathrm{K}_{\mathrm{a} 1} \mathrm{~K}_{\mathrm{a} 2}\left[\mathrm{H}_{3} \mathrm{O}^{+}\right]^{-2}\right)$

Because of the rather strong acid character of $\mathrm{HSO}_{4}{ }^{-}$at a $\mathrm{pH}$ higher than 4 the only form of sulphate present in the solution is $\mathrm{SO}_{4}{ }^{2-}$. In nutrient solutions the dissociation of sulphate does not influence the composition nor the bioavailability of sulphate.

\section{Potassiumhydroxide, calciumhydroxide and magnesium hydroxide}

The hydroxides of potassium, calcium and magnesium are strong bases, completely dissociated in the $\mathrm{pH}$ range from 1 to 14 (Figures 4,5 and 6). The hydrolysation reaction of these three cations does not influence their bioavailability, nor the composition of the nutrient solution.

$$
\begin{array}{lll}
\mathrm{KOH} & \rightarrow \mathrm{K}^{+}+\mathrm{OH}^{-} & \mathrm{K}_{\mathrm{b}}=10^{14.5} \\
\mathrm{Ca}(\mathrm{OH})_{2} & \rightarrow \mathrm{CaOH}^{+}+\mathrm{OH}^{-} & \mathrm{K}_{\mathrm{b} 1}=10^{15.3}
\end{array}
$$




$$
\begin{array}{lll}
\mathrm{CaOH}^{+} & \rightarrow \mathrm{Ca}^{2+}+\mathrm{OH}^{-} & \mathrm{K}_{\mathrm{b} 2}=10^{12.7} \\
\mathrm{Mg}(\mathrm{OH})_{2} & \rightarrow \mathrm{MgOH}^{+}+\mathrm{OH}^{-} & \mathrm{K}_{\mathrm{b} 1}=10^{16.5} \\
\mathrm{MgOH}^{+} \rightarrow \mathrm{Mg}^{2+}+\mathrm{OH}^{-} & \mathrm{K}_{\mathrm{b} 2}=10^{11.5}
\end{array}
$$

\section{$\underline{\text { 5. Ammonium }}$}

In the past several standard nutrient solutions were developed, containing both nitrate and ammonium as nitrogen source, aiming at a more stable $\mathrm{pH}$ of the nutrient solution. Ammonium ions in a nutrient solution are more or less toxic for plants growing under aerobic conditions. As cited by Hewitt (1966), the toxicity of ammonium is determined by the external cell $\mathrm{pH}$, determing the rate of uptake, and the internal cell $\mathrm{pH}$, determing the concentration of undissociated ammonium (Warren, 1962). There is no problem in supplying $\mathrm{NH}_{4}^{+}$to the soil. The ions will be fixed and not freely available for the plantroots. The ammonium ions will gradually be transferred to nitrate by nitrification processes. This nitrogen form is freely available for plant roots. In general never more than $10 \%$ of the total nitrogen content may be supplied in the form of $\mathrm{NH}_{4}^{+}$(Steiner 1984). Ammonium is a weak acid, containing only one ionisable proton:

$$
\mathrm{NH}_{4}^{+}+\mathrm{H}_{2} \mathrm{O} \leftrightarrow \mathrm{H}_{3} \mathrm{O}^{+}+\mathrm{NH}_{3} \quad \mathrm{~K}_{\mathrm{a}}=10^{-9.2}
$$

The fraction of each dissociation form present in an aqueous ammonium solution in function of the $\mathrm{pH}$ can be calculated as follows:

1. The fraction $\mathrm{NH}_{4}^{+}: \alpha_{0}=1 / \mathrm{A}$

2. The fraction $\mathrm{NH}_{3}: \alpha_{1}=\left(\mathrm{K}_{\mathrm{a} 1}\left[\mathrm{H}_{3} \mathrm{O}^{+}\right]^{-1}\right) / \mathrm{A}$

$$
\text { With } \mathrm{A}=1+\left(\mathrm{K}_{\mathrm{a} 1}\left[\mathrm{H}_{3} \mathrm{O}^{+}\right]^{-1}\right)
$$

Up to a $\mathrm{pH}$ of 7.5 only $\mathrm{NH}_{4}{ }^{+}$is present (Figure 7). Between a $\mathrm{pH}$ of 7.5 to $10.5, \mathrm{NH}_{4}{ }^{+}$is gradually replaced by $\mathrm{NH}_{3}$. Since the $\mathrm{pH}$ of most nutrient solutions varies from 4 to 7 , dissociation reactions will not influence the bioavailibility of ammonium nor the composition of the nutrient solutions.

\section{Carbonic acid}


Most of Belgian tap-water contains bicarbonate in concentrations that sometimes exceed the 5 millimolar range. If nutrient solutions are made, using tap water, dissociation reactions of carbonic acid are to be taken into account. Carbonic acid is a weak acid that ionises in two distinct steps:

$$
\begin{array}{ll}
\text { 1. } \mathrm{H}_{2} \mathrm{CO}_{3}+\mathrm{H}_{2} \mathrm{O} \leftrightarrow \mathrm{H}_{3} \mathrm{O}^{+}+\mathrm{HCO}_{3}^{-} & \mathrm{K}_{\mathrm{a} 1}=10^{-6.3} \\
\text { 2. } \mathrm{HCO}_{3}^{-}+\mathrm{H}_{2} \mathrm{O} \leftrightarrow \mathrm{H}_{3} \mathrm{O}^{+}+\mathrm{CO}_{3}{ }^{2-} & \mathrm{K}_{\mathrm{a} 2}=10^{-10.3}
\end{array}
$$

$\mathrm{H}_{2} \mathrm{CO}_{3}$ does not exist as a stable molecule. It is an equilibrium of $\mathrm{H}_{2} \mathrm{O}$ and dissolved $\mathrm{CO}_{2} . \quad \mathrm{CO}_{2(\mathrm{aq})}$ is often referred to as $\mathrm{H}_{2} \mathrm{CO}_{3(\mathrm{aq})}$ to emphasise its acidic properties. The value given for $\mathrm{K}_{\mathrm{a} 1}$ is actually for the reaction:

$$
\mathrm{CO}_{2(\mathrm{aq})}+2 \mathrm{H}_{2} \mathrm{O} \leftrightarrow \mathrm{H}_{3} \mathrm{O}^{+}+\mathrm{HCO}_{3}^{-}
$$

Generally aqueous solutions of $\mathrm{CO}_{2}$ are treated as if the $\mathrm{CO}_{2(\mathrm{aq})}$ is first converted to $\mathrm{H}_{2} \mathrm{CO}_{3}$ and then dissociates (Petrucci et al, '93). Until a $\mathrm{pH}$ of 4.5 only $\mathrm{H}_{2} \mathrm{CO}_{3}$ is present in an aqueous solution, containing only carbonic acid (Figure 8). If the $\mathrm{pH}$ increases from 4.5 to $8, \mathrm{H}_{2} \mathrm{CO}_{3}$ is gradually replaced by $\mathrm{HCO}_{3}{ }^{-}$. Increasing the $\mathrm{pH}$ from 8.5 to $12.5, \mathrm{HCO}_{3}{ }^{-}$is replaced by $\mathrm{CO}_{3}{ }^{2-}$. In nutrient solutions with a $\mathrm{pH}$ lower than 4.5 carbonic acid will not be dissociated. If the $\mathrm{pH}$ rises above 4.5, carbonic acid dissociates and the composition of the nutrient solution changes. The fraction $\mathrm{H}_{2} \mathrm{CO}_{3}\left(\alpha_{0}\right), \mathrm{HCO}_{3}{ }^{-}\left(\alpha_{1}\right)$ and $\mathrm{CO}_{3}{ }^{2-}\left(\alpha_{2}\right)$, present in an aqueous solution containing only carbonic acid, in function of the $\mathrm{pH}$ can be calculated as follows:

1. The fraction $\mathrm{H}_{2} \mathrm{CO}_{3}: \alpha_{0}=1 / \mathrm{A}$

2. The fraction $\mathrm{HCO}_{3}^{-}: \alpha_{1}=\left(\mathrm{K}_{\mathrm{a} 1}\left[\mathrm{H}_{3} \mathrm{O}^{+}\right]^{-1}\right) / \mathrm{A}$

3. The fraction $\mathrm{CO}_{3}{ }^{2-}: \alpha_{2}=\left(\mathrm{K}_{\mathrm{a} 1} \mathrm{~K}_{\mathrm{a} 2}\left[\mathrm{H}_{3} \mathrm{O}^{+}\right]^{-2}\right) / \mathrm{A}$

With $\mathrm{A}=1+\left(\mathrm{K}_{\mathrm{a} 1}\left[\mathrm{H}_{3} \mathrm{O}^{+}\right]^{-1}\right)+\left(\mathrm{K}_{\mathrm{a} 1} \mathrm{~K}_{\mathrm{a} 2}\left[\mathrm{H}_{3} \mathrm{O}^{+}\right]^{-2}\right)$

In practice all nutrient solutions are in equilibrium with a partial atmospheric $\mathrm{CO}_{2}(\mathrm{~g})$ pressure of at least 35.5 pascal atmosphere. In greenhouses this partial $\mathrm{CO}_{2}$ pressure if often much higher due to the supply of $\mathrm{CO}_{2}$ to the plants. Small amounts of $\mathrm{CO}_{2}(\mathrm{~g})\left(1.4 \times 10^{-5} \mathrm{~mol} / \mathrm{l}\right)$ will dissolve in the nutrient 
solutions and form carbonic acid. This effect is not accounted for since it is only a neglectable small amount of $\mathrm{CO}_{2}(\mathrm{~g})$ that dissolves.

\section{CONCLUSION}

A good knowledge of the chemical reactions occurring in nutrient solutions is the first prerequisite in hydroponic plant nutritional research. Due to the strong acid properties of nitric acid and sulphuric acid, their conjugated base pair, respectively nitrate and sulphate are very weak bases. This means that if nitrate and sulphate ions are added to the nutrient solution as a salt they will not hydrolyse. If they are added as an acid they immediately dissociate.

The strong basic properties of potassiumhydroxide, magnesiumhydroxide and calciumhydroxide, see to it that they immediately and completely dissociate. Their conjugated acid pair, respectively $\mathrm{K}^{+}, \mathrm{Mg}^{2+}$ and $\mathrm{Ca}^{2+}$ are very weak acids and will therefore not bind with $\mathrm{OH}^{-}$.

$\mathrm{NH}_{4}{ }^{+}$is a weak acid that only dissociates at $\mathrm{pH} 7.5$, outside the $\mathrm{pH}$ range of nutrient solutions $(4-7)$. So in nutrient solutions no $\mathrm{NH}_{3}$ will be present.

The dissociation reactions involved with $\mathrm{NO}_{3}{ }^{-}, \mathrm{SO}_{4}{ }^{2-}, \mathrm{K}^{+}, \mathrm{Ca}^{2+}, \mathrm{Mg}^{2+}$ and $\mathrm{NH}_{4}{ }^{+}$do not influence their bioavailability within the $\mathrm{pH}$ range of nutrient solutions.

Within the $\mathrm{pH}$ range of nutrient solutions dissociation reactions influence the bioavailability of phosphate and carbonate. In comparing plant response to nutrient solution with the same amount of phosphate and/or carbonate at a different $\mathrm{pH}$, not only the $\mathrm{pH}$ differs but also the bioavailability of these ions. This confounding between $\mathrm{pH}$ and bioavailability should be taken into account in interpreting the results of such experiments. 


\section{REFERENCES}

Cotton, F.A. and Wilkinson, G. 1980. Advanced inorganic chemistry, a comprehensive text. 4th edition, John Wiley and Sons, Inc., New York.

Hai, Tang Van and Laudelout, H. 1966. Absorption of phosphate by rice roots. Ann. Physiol. Vég 8,13-24.

Hewitt, E.J., 1966. Sand and water culture methods used in the study of plant nutrition. Technical communication No 22 (revised). Commonwealth Bureau of Horticulture and Plantation Crops, East malling, Maidstone, Kent, England.

Petrucci, R.H. and Harwood, W.S. 1993. General Chemistry. Principles and modern applications. In : Corey P.F., Macmilan Publishing Company, New York.

Skoog, D.A. and West, D.M. 1976. Fundamentals of analytical chemistry. Third edition. In: Holt, Rinehart and Winston, New York.

Steiner, A.A. 1984. The universal nutrient solution. ISOSC Proc. 6th International Congress on Soilless Culture, 633-649.

Warren, K.S., 1962. Ammonia toxicity and pH. Nature 195:47 (cited by Hewitt 1966). 


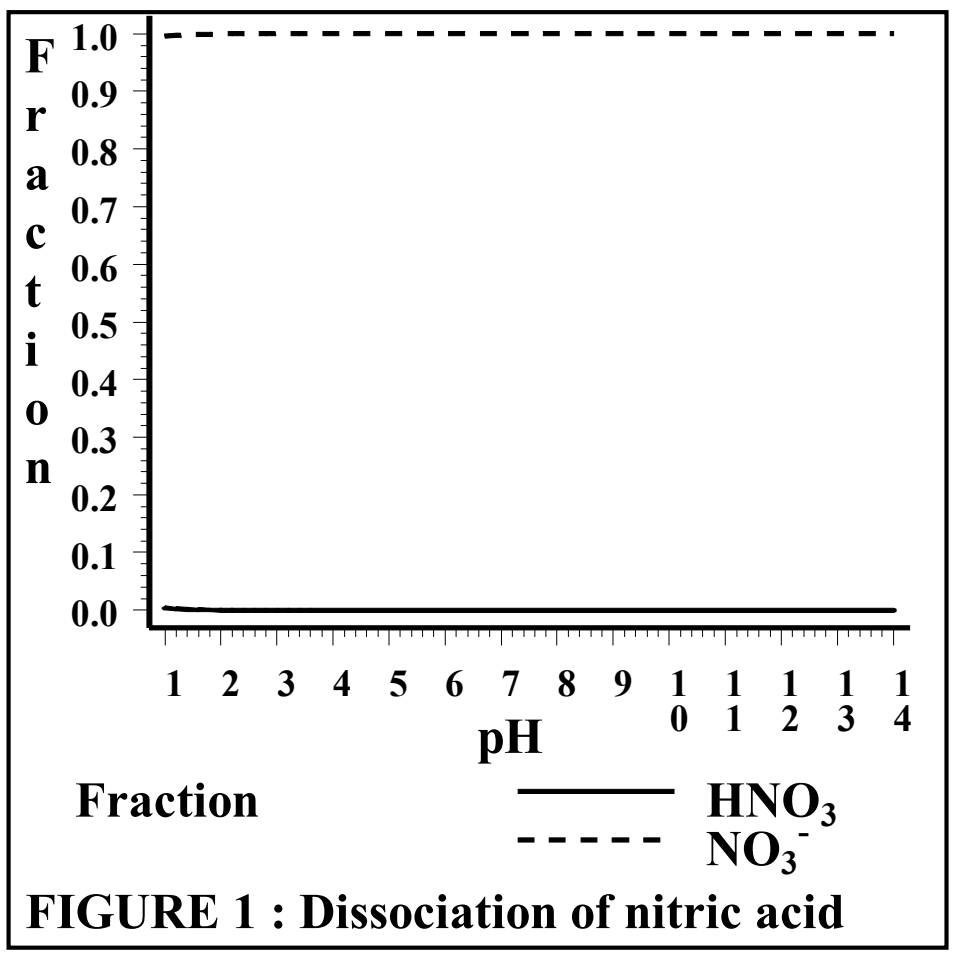




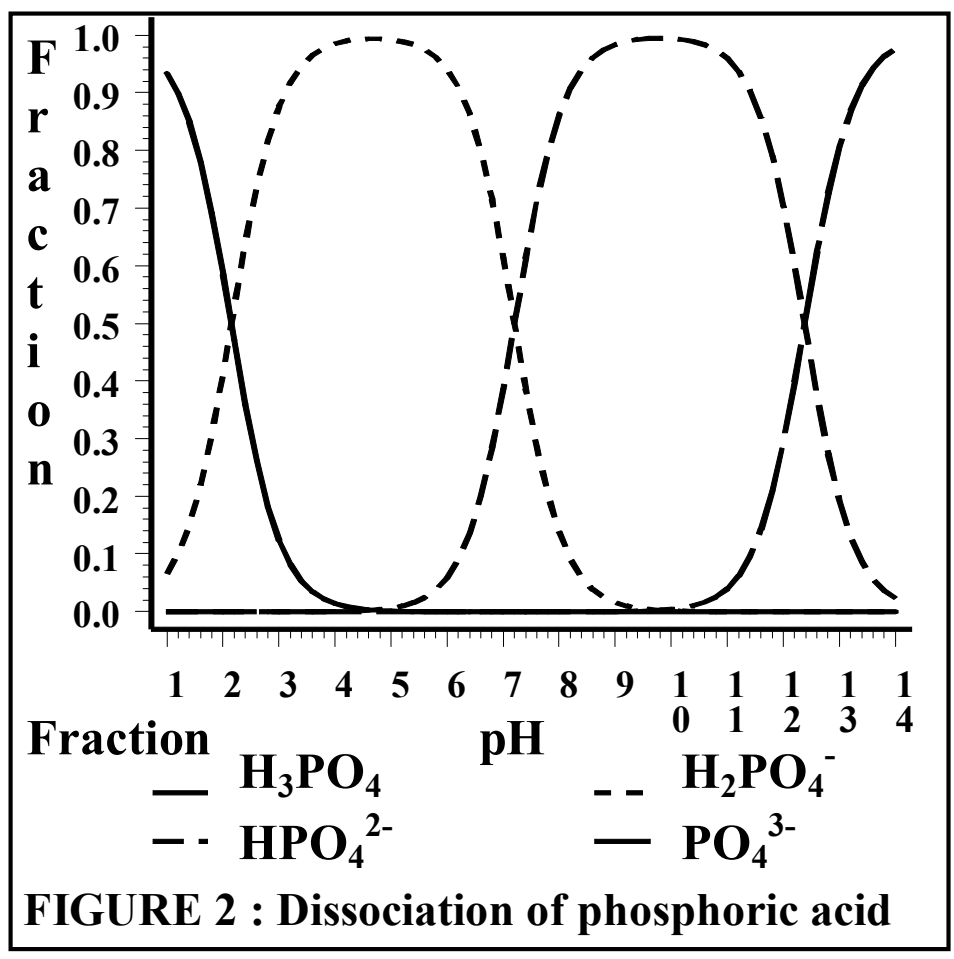




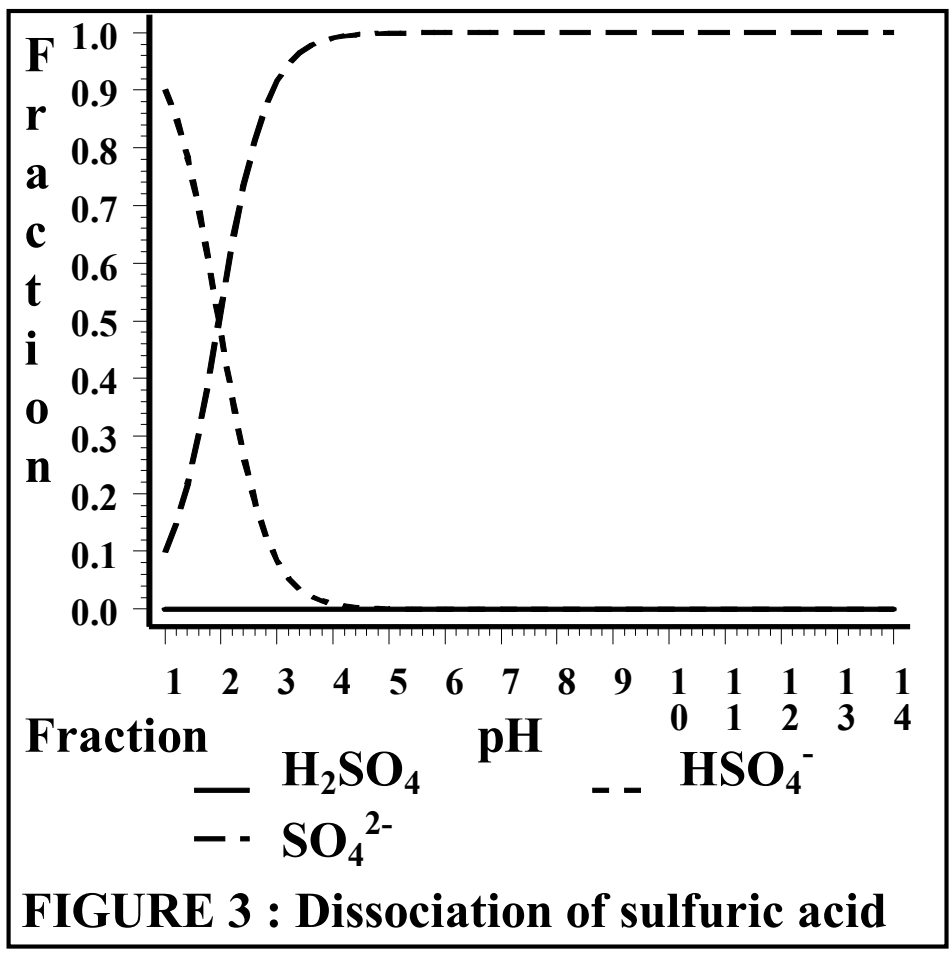




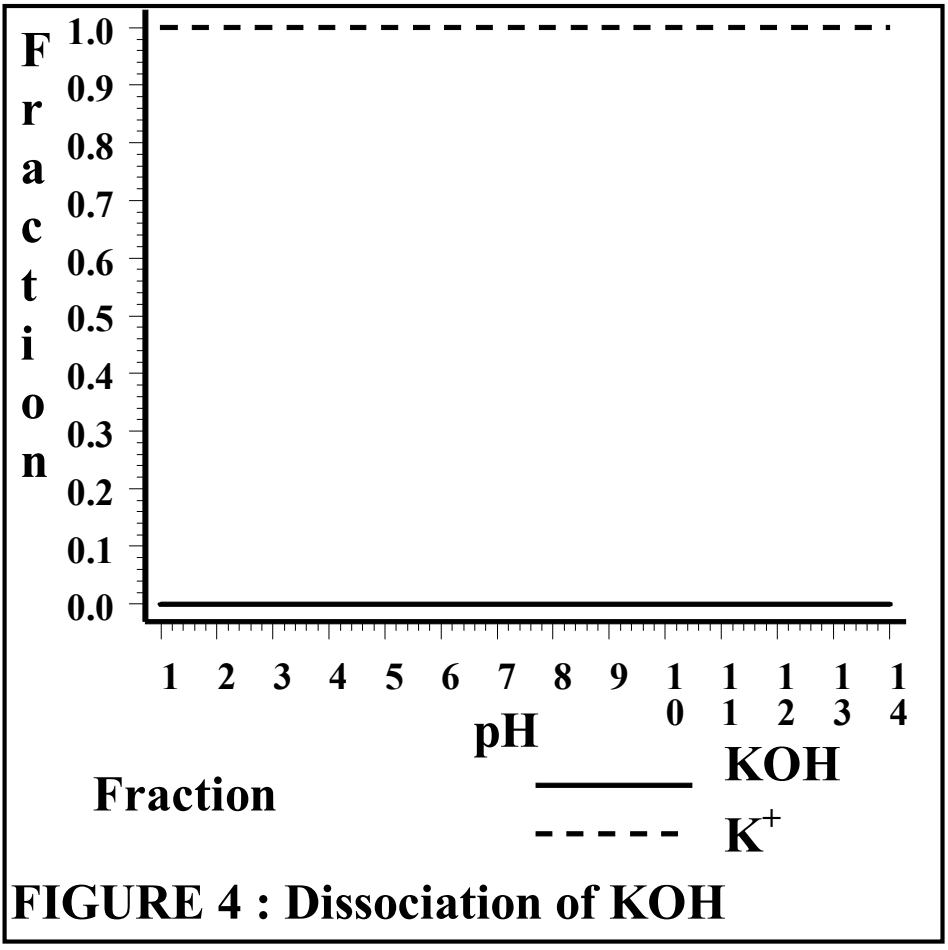




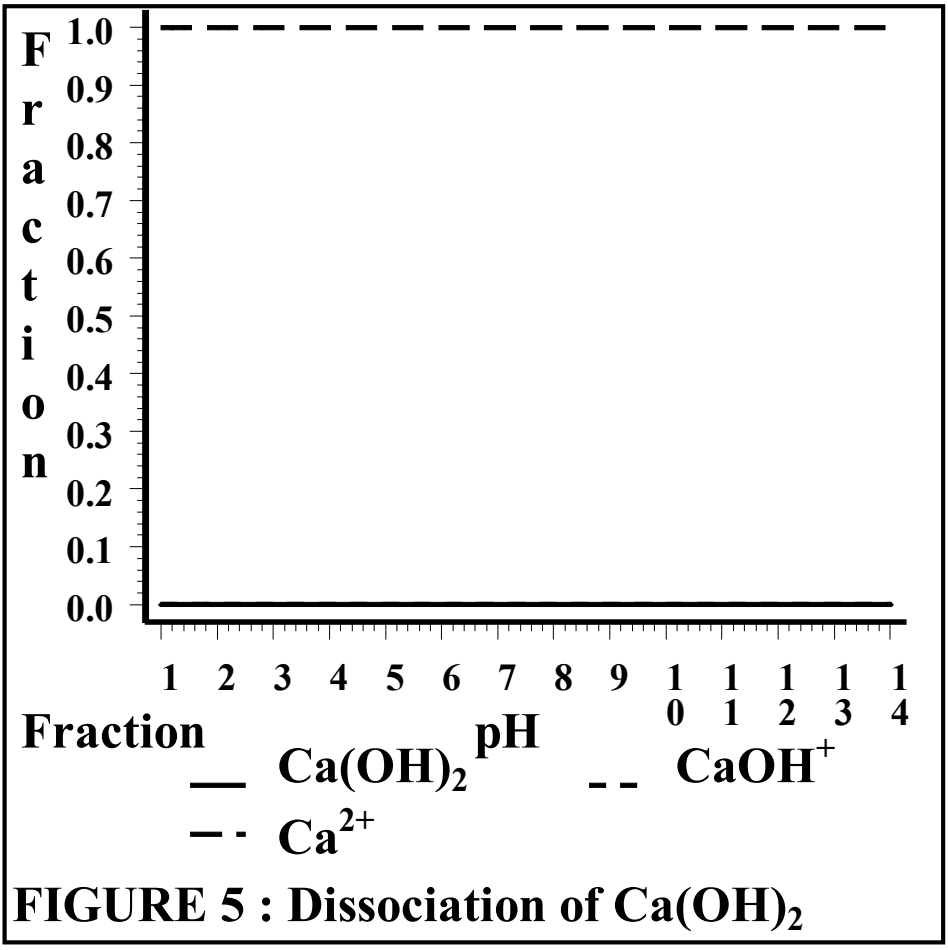




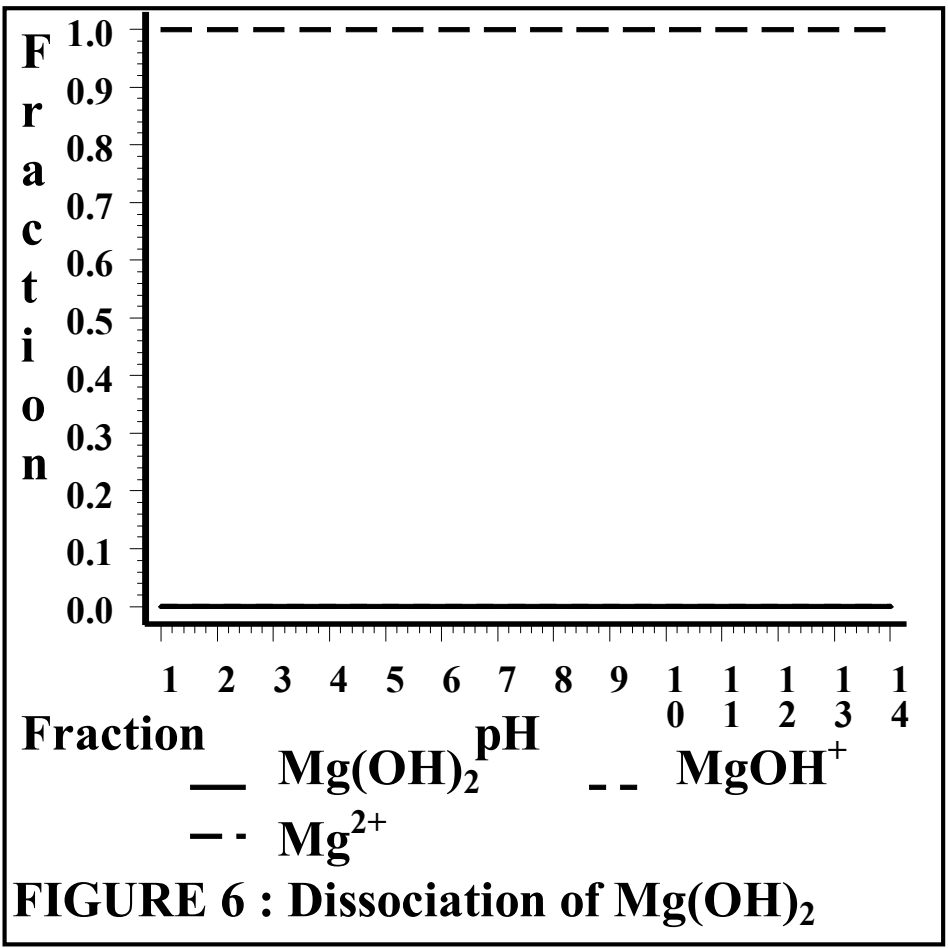




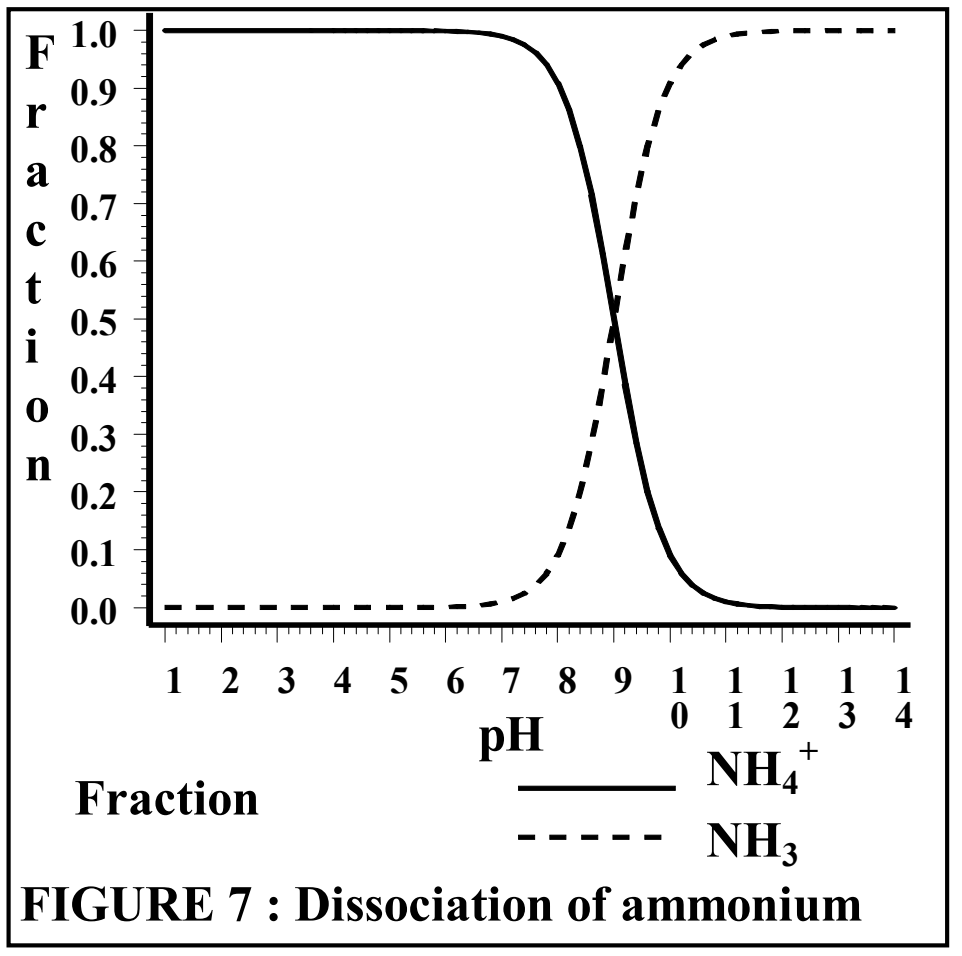




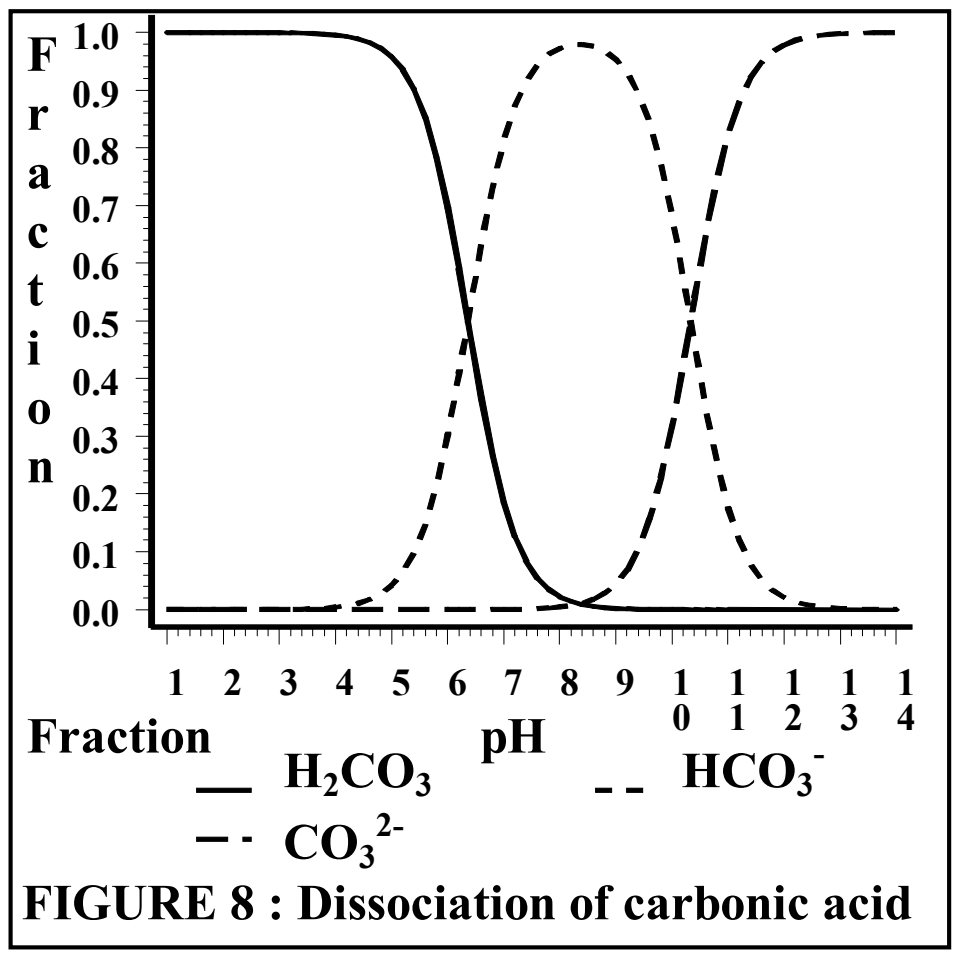

